INTERNATIONAL HIGHER EDUCATION, Number 73 Fall 2013

Pages 6-7

\title{
International Recruitment: Oversight and Standards
}

\author{
DAVID ENGBERG
}

David Engberg is executive director of the Global Opportunities Group, a USbased international education services organization. E-mail: dave@g-ogroup.com.

The use of paid agents to recruit international students remains a contentious issue in US higher education. Proponents argue that paying agents is inconsistent with well-established domestic student recruitment practices, incentivizes agents to put their own financial interests ahead of students' academic interests, and contributes to application fraud. Advocates claim that working with paid agents costs less and is a lower risk than managing international recruitment on their own and, by providing access to multiple markets, that it helps diversify international student enrollments.

In May 2013, the National Association for College Admission Counseling (NACAC) released a much-anticipated commission report on international student recruitment. It detailed concerns related to commission-based agents, but recommended that NACAC eliminates its ban on member institutions using paid agents.

Since its publication, the report has been widely criticized by individuals on both sides of the debate. Those opposed to working with agents believe that 
NACAC compromises its integrity and credibility by allowing a practice that risks putting revenue ahead of students' interests. The central complaint among supporters of lifting the ban is that the report does not advance discussions related to international recruitment standards and quality in the United States.

This criticism is especially salient. Given (1) the international spike in demand for admission at US institutions, especially at the undergraduate level, (2) the ability of international students (or their governments) to pay the full cost

of instruction, and (3) the fiscal challenges faced by many institutions, it can be anticipated that additional campuses will seek to enroll more and more international students and use third-party agencies to help them.

\section{Current Status}

The United Kingdom and Australia are well-known for their use of agents to recruit international students to tertiary institutions. Each has well-developed regulatory systems, providing oversight of agent-university relationships-not so in the United States. Here, the federal government gives off mixed signals. State Department-funded EducationUSA offices around the world are prohibited from working commercial recruiters, for fear that doing so would create a perception of bias; the Departments of Commerce and Homeland Security are both involved in activities and events that bring universities and commercial recruitment agencies together and encourage them working together. With the exception of the American International Recruitment Council (AIRC), a Washington, DC-based nonprofit founded in 2008, there are no US organizations dedicated to the oversight of international student recruitment. 
According to its organizational principals, AIRC's mission is to develop standards of ethical practice related to international student recruitment, certify agencies determined to be in compliance with AIRC's standards, and develop best practices and training to aid agencies and institutions to better serve students. To receive certification, an agency must complete a self-evaluation report, undergo a site visit, and pass a vote by AIRC's Board of Directors. Certification lasts five years, during which time approved agencies may use AIRC's logo to market their services. Once certified, agencies must submit annual reports to remain in good standing and pay an annual membership fee. After five years, they must repeat the entire self- and external-review process to be recertified.

Given the absence of other US organizations, actively involved in international recruitment standards development and oversight, AIRC's work is laudable. Their certification process is lacking, however, in several substantive ways. It is time consuming and expensive: AIRC's Web site instructs agencies to plan for an eight-to-nine month certification process, with a first-year cost of $\$ 10,000$. Each year, thereafter, small agencies (less than 500 student placements per annum) must pay a $\$ 2,000$ membership fee to retain their certification. For large agencies, the annual fee is $\$ 4,000$. Small "mom and pop" agencies still dominate the recruitment market in many countries, especially in Asia. Their cost of AIRC certification and membership $-\$ 20,000$ over five years-means that most will not seek certification.

The subjective nature of AIRC's standards is another concern, making them difficult to quantify and review. Is it possible, for example, to measure whether all of an agency's employees "are competent, well informed, reputable, 
and act at all times in the best interest of the applicant and institutions"? About determining whether the agency is managing its financial resources to best effect, representing itself honestly in advertising materials or ensuring that subagents or others employed offsite to manage, all or part of the recruitment process are in compliance with AIRC's standards?

Finally, and perhaps most significantly, AIRC's review/certification process is designed to certify agencies, rather than the individuals working at agencies. As a result, it does little to ensure that the counselors who are interacting with students actually understand the US higher education system, how admissions offices function, or the nuances of the US immigration system. AIRC, or another US organization, would do well to offer targeted training, like International Consultants for Education and Fairs (ICEF) and the British Council do in Europe, or certification, like Australian-based Professional International Education Resources (PIER) does for the actual counselors responsible for student placements in the US market.

\section{The PATH ForWARD}

Ultimately, the best advice for US educational institutions interested in partnering with an international student recruitment agency, or agencies, is to develop their own set of standards and procedures. Some campuses-the University of Cincinnati and Wichita State University, for example-have done this successfully. Most have not, however, and are ill-prepared to effectively partner with agencies when they come calling. For instance, at many institutions, single individuals are responsible for both international recruitment and admissions, an arrangement that can lead to conflicts of interest. In addition, 
many campuses, even those seeking to enroll more international students, lack policies for vetting, contracting with, and evaluating the performance of commission-based agents. Thus, regardless of the external organizations engaged in recruitment agency standards and quality assurance, campuses that chose to outsource aspects of their international recruitment must establish plans and best practices appropriate to meeting their own enrollment objectives. 